\title{
О ПРОБЛЕМАХ ПОНЯТИЯ И КВАЛИФИКАЦИИ НЕИЗГЛАДИМОГО ОБЕЗОБРАЖИВАНИЯ ЛИЦА
}

Аннотация: В статье исследован квалифицирующий признак причинения тяжкого вреда здоровью - неизгладимое обезображивание лица, которое не причиняет реального ущеерба человека, выражающего стойкую утрату общей трудоспособности или полную утрату профессиональной трудоспособности. Обращено внимание на использование в научной литературе термина «обезображение», что противоречит действующему уголовному законодательству, которое содержит термин «обезображивание». Автор отмечает, что предложение отдельных учёных о возможности установления уголовной ответственности не только за обезображивания лица, но любой части тела человека, является спорныл, так как лицо - это открытая часть тела, воспринимаемая окружаюшими и вызывающая у них отрицательную реакцию. Предлагаемые дополнения ставят знак равенства между различными частями тела человека и его лицом. Автор считает, что при решении вопроса об обезображивании лица необходимо учитывать мнение потерпевщего о красоте, а также его национальные анатомические особенности в совокупности: пол, возраст, род занятий и т.д. Анализ практики и действующего законодательства позволив условиях действия приничипа состязательности сторон, суд не может устанавливать степень тяжести вреда, причиненного здоровью человека, выразившегося в неизгладимом обезображивании его лица. В качестве решения существующей проблемь предложено предоставить следователю право назначить проведение эстетической экспертизы, поручив её производство художникам-портретистам или специалистам в области изобразительного искусства, которые в заключении обоснуют объективные критерии наличие или отсутствие обезображивания лица, учитывая национальные анатомические особенности и представления о красоте и неповторимости. Для закрепления данного права необходимо внести изменения в Постановление Правительства Российской Федерации № 522 от 17 августа 2007 г., а также в Приказ Министерства здравоохранения и сочиального развития РФ от 24 апреля 2008 г. № 194н,: «степень обезображивания лица определяется экспертом, обладающим специиальными познания в области эстетической оценки внешнего облика человека».

Ключевые слова: Лицо, части тела, обезображение, обезображивание, вред здоровью, повреждение, преступление, квалификация, эстетическая экспертиза, ответственность.

Abstract: The article examines the qualifying factors of inflicting a severe harm to a person's health-a permanent disfigurement of the face, which does not necessarily pose a serious threat to the subject's health in form of preventing them of being able to perform day-to-day duties or a complete loss of ability to perform work functions. The author notes that the proposal of some scholars to introduce criminal responsibility not only for disfigurement of the face, but also any other part of the body, is rather controversial, as face is an exposed part of the human body and is a part of forming a perception about them and can often invoke a negative reaction towards them. The proposed amendments place the face in the same position as other parts of the body. The author believes that in resolving such matters on the disfigurement of the face it is necessary to consider the victim's perception of beauty, as well as their national anatomic features as a whole: gender, age, type of activities, etc. As a solution to this problem, a proposal is made to allow the prosecutor to request an aesthetic examination, entrusting the task to portrait artists or specialists in the area of visual arts, who would provide the criteria on the presence or absence of disfigurement of the face, taking into account the national features and perceptions on beauty and uniqueness.

Keywords: Face, body parts, disfigurement, disfiguration, bodily harm, damage, crime, qualification, aesthetic examination, responsibility.

реди квалифицирующих признаков причинения тяжкого вреда здоровью Уголовный кодекс Российской Федерации предусматривает неизгладимое обезображивание лица, которое не причиняет реального ущерба человека, выражающего стойкую утрату общей трудоспособности или полную утрату профессиональной трудоспособности (ч.1 ст. 114 УК РФ).
Обезображивание представляет собой телесное повреждение анатомической целости тканей лица, придающее последнему уродливый, неприятный, отталкивающий вид.

Лицо доступно непосредственно-чувственному зрительному восприятию, которое при его обезображивании вызывает у окружающих отрицательную эмоциональную реакцию, тем самым причиняет человеку не только мо- 
DOI: $10.7256 / 1811-9018.2015 .4 .13556$

При цитировании этой статьи сноска на doi обязательна

\section{Право и политика 4 (184) 2015}

ральные страдания, но и, в частности, влияет на выбор профессиональной деятельности, может привести к психическому расстройству, к самоубийству. Эти обстоятельства исторически признаются в уголовном законодательстве достаточным основанием для отнесения обезображивания лица к квалифицирующим признакам ${ }^{1}$.

В действующем уголовном законодательстве используется термин «обезображивание». С момента появления этого термина в юридической научной литературе, учебниках, правилах и законодательных актах встречается употребление слов «обезображение» и «обезображивание». Эти слова, по мнению отдельных учёных, можно отнести к устаревшим (архаизмы) или словам, в прошлом обозначавшим те или иные понятия (историзмы), но правильно будет их относить к словам, употребляемым лицами определенных профессий (профессионализмы), в данном случае юристами и врачами. Обезображивание от глагола несовершенного вида «обезображивать», т.е. это процесс ${ }^{2}$.

Как процесс в уголовном кодексе используются и другие глаголы несовершенного вида: доведение, заражение, использование, истязание, нарушение, оскорбление, оставление, понуждение, похищение, принуждение и др. Если в любой несудебной деятельности неправильное употребление терминов нежелательно, то в судебной необходимо использовать термины, содержащиеся в уголовном законе, в частности, обезображивание. Обезображивание - то умышленные действия, направленные на искажение анатомической целостности внешних черт лица, придающие ему отталкивающий, уродливый вид.

В принципе обезображивание может быть любой части тела ${ }^{3}$. Однако Уголовный кодекс Российской Федерации признак причинения тяжкого вреда здоровью путём обезображивания ограничивает областью лица. Так как среди учёных и практических работников существуют различные мнения, какие части тела являются лицом, то при решении вопроса о полной или частичной утрате, например, ушной раковины, ее деформации, а также наличие грубых рубцов на переднебоковой поверхности шеи, суды исходили из законодательства и юридического опыта прошлых лет.

\footnotetext{
${ }^{1}$ См.: Познышев С.В. Очерк основных начал науки уголовного права. Особенная часть. М., 1923. С.24; Капустин A.B. О некоторых вопросах судебно-медицинской экспертизы степени тяжести телесных повреждений // Суд. - мед. эксперт.1991.№3. С.41.

${ }^{2}$ См.: Путинцев В.А., Абрамов С.С. Неизгладимое обезображивание лица // Судебно-медицинская экспертиза. №3. 2011. - С. 62.

${ }^{3}$ См.: Галюкова М.И. Неизгладимое обезображивание лица как признак тяжкого вреда здоровью. URL: http:// www.rusnauka.com/8. NPE2007/Pravo/18984.doc.htm).
}

Законодатель использует термин «лицо», следовательно, другие участки тела, расположенные за пределами указанных границ, не относятся к лицу и повреждения на них не могут быть оценены по признаку неизгладимого обезображивания лица. По мнению А.Г. Корчагина и Н.П. Федотовой такое решение вопроса вряд ли будет правильным. Ведь шея или волосистый покров головы в целом создают дополнительное впечатление о чертах лица, более того, органически вписываются в черты лица потерпевшего. Повреждение, например, шеи в передней видимой части будет придавать в целом отталкивающий, безобразный вид 4 . Если согласиться с указанным мнением, то тем самым произвольно расширяются границы лица, что будет свидетельствовать о применении судом аналогии в уголовном праве, а это является основанием к оспариванию квалификации содеянного в вышестоящих судах.

Спорными остаются верхняя граница лица (в практике они условны и в норме ограничены краями волосистой части в лобной и височных областях), ушные раковины (по анатомической классификации относящиеся к височным областям) и зубы (эстетическая стоматология рассматривает фронтальные зубы важным элементом улыбки и красоты лица) $)^{5}$. С медицинской точки зрения, лицо - это передний отдел головы человека, ограниченный сверху краем волосяного покрова головы, снизу - углами и нижним краем нижней челюсти, с боков - краями ветвей нижней челюсти и основанием ушных раковин ${ }^{6}$.

Существует мнение, что границы лица проходят вверху по линии, соответствующей верхнему краю глазниц, далее по скуловому отростку лобной кости, лобному отростку скуловой кости, скуловой дуге, наружному слуховому проходу, снаружи - по заднему краю ветви нижней челюсти до ее угла, снизу - по краю тела нижней челюсти до подбородочного возвышения 7 .

\footnotetext{
${ }^{4}$ См.: Корчагин А.Г., Федотова Н.П. Уголовно-правовая политика борьбы с преступлениями умышленного причинения тяжкого вреда здоровью. - М.: Изд-во «Юрлитинформ», 2014. - С.57.

${ }^{5}$ См.: Михайлов С.C. (ред.). Международная анатомическая номенклатура (с официальным списком русских эквивалентов). - М: Медицина 1980; Дыскин Е.А., Исаков В.Д., Колкутин В.В., Путинцев B.A. Некоторые экспертные критерии неизгладимости при повреждениях лица // Актуальные вопросы теории и практики судебной медицины. Сборник трудов. - Санкт-Петербург. 1996.

${ }^{6}$ См.: Путинцев В.А., Абрамов С.С. Неизгладимое обезображивание лица // Судебно-медицинская экспертиза. №3. 2011. - С. 60.

${ }^{7}$ См.: Топографическая анатомия и оперативная хирургия: учебник / Каган И.И., Чемезов С.В. 2009. http://www.studmedlib. $\mathrm{ru} /$ documents/ISBN9785970410578-A010.html. Дата обращения 20.10. 2014 г.
} 
Как одни, так и другие не включают ушные раковины и волосяной покров головы в границы лица. По мнению В.А. Путинцев и С.С. Абрамова потеря волос на голове для женщины - косметический дефект, точно так же, как и потеря усов или бороды у мужчин, проживающих в регионах, где это считается символом мужественности или связано с религиозным саном ${ }^{8}$.

В клинической практике врачи используют Российскую и Международную анатомические классификации областей лица:

Российская классификация области лица (топографическая школа В.Н. Шевкуненко): область глазницы (правая и левая); подглазничная область (правая и левая); скуловая область; область носа; область рта; щечная область (правая и левая); околоушно-жевательная область (правая и левая); подбородочная область.

Международная классификация области лица (номенклатура областей тела человека по PNA): область глазницы (правая и левая); подглазничная область (правая и левая); скуловая область; область носа; область рта; щечная область (правая и левая); подбородочная область 9

Российская классификация в отличие от международной классификации в область лица включает околоушно-жевательную область (правая и левая).

У учёных-юристов также нет единства по данному вопросу. Не вдаваясь в дискуссию, отметим лишь наиболее интересные, с нашей точки зрения. Так, по мнению одних, в признаки лица анфас входят: высота ушной раковины, оттопыренность ушной раковины, контур противозавитка, контур козелка. В признаки лица в профиль входят: ширина ушной раковины, внешний и внутренний контуры завитка, контур края мочки, контур противокозелка ${ }^{10}$. Другие В.Е. Эминов и Г.С. Юрин к элементам внешности лица относили волосяной покров головы (причёски), брови, глаза, нос, рот (губы), контур нижней части лица (подбородок), ушные раковины ${ }^{11}$. В своё время Д.С. Читлов предложил предусмотреть уго-

${ }^{8}$ См.: Путинцев В.А., Абрамов С.С. Неизгладимое обезображивание лица // Судебно-медицинская экспертиза. №3. 2011. - С. 61.

${ }^{9}$ См.: Там же. - C. 60.

${ }^{10}$ См.: Пантелеев И.Ф. Идентификация человека по признакам внешности // Криминалистика: Учебник / Под ред. И.Ф. Пантелеева, Н.А. Селиванова. - М.: Юрид. лит., 1993. - С.301; Беляков А.А. Идентификация личности человека по признакам внешности // Криминалистика: уче. Для вузов /И.Ф. Герасимов, Л.Я. Драпкин, И.П. Ищенко и др.; Под. ред. И.Ф. Герасимова, Л.Я. Драпкина. М.: Высш. шк., 1994. - С. 184-186.

${ }^{11}$ См.: Эминов В.Е., Юрин Г.С. Использование при расследовании составных фотографических и рисованных портретов. - М.: ВИИПП, 1973. - С. 16. ловную ответственность за неизгладимое обезображивание не только лица, но и шеи ${ }^{12}$.

По мнению И.В. Поликарповой данный признак должен охватывать участков тела, непосредственно прилегающих к лицу ${ }^{13}$. Она полагает, что только рубцы на видимых частях тела могут придавать отталкивающий вид человеку, а рубцы, например, на спине вряд ли могут быть признаны таковыми ${ }^{14}$. Речь здесь следует вести об отрытых участках тела, которые за одеждой не всегда можно скрыть. Это, прежде всего, лицо человека, шея, и плечи, волосистый покров головы ${ }^{15}$.

По мнению А.А. Шаматульского, признак обезображивания должен оцениваться, независимо от возможности скрыть дефект одеждой или аксессуарами $^{16}$. Существуют жизненные ситуации, когда человек остаётся без одежды, например, бассейн, пляж, медицинский осмотр и др., и следы обезображивания тела становятся видимыми для посторонних лиц. Важно учитывать, что они причиняют психические страдания человеку, приносят ему социальные ограничения.

Если из-за отсутствия чётких границ лица можно говорить о принадлежности к нему шеи, ушных раковин, то установление уголовной ответственности за обезображивание естественного состояния иных частей тела и существенное видоизменение естественного состояния опорно-двигательного аппарата (нарушение осанки тела, хромоты ног, асимметрии рук и ног, отсутствие предплечья, кисти, стопы и др.), является спорным ${ }^{17}$.

Безусловно, можно говорить об обезображивании любой части тела, но не в рамках уголовной ответственности ч.1 ст. 111 УК РФ, так как они могут относиться к категории вреда здоровью средней тяжести или легкого вреда здоровью. Все эти дополнения об установлении

\footnotetext{
${ }^{12}$ См.: Читлов Д.С. Охрана здоровья граждан от тяжких насильственных посягательств. - Саратов, 1974. - С.59

${ }^{13}$ Поликарпова И.В. Уголовная ответственность за умышленное причинение тяжкого вреда здоровью. - М.: Изд-во «Юрлитинформ», 2009. - С.103.

${ }^{14}$ См.: Поликарпова И.В. Уголовная политика России в отношении посягательств на здоровье и ее влияние на квалификацию преступлений: на примере ответственности за умышленное причинение тяжкого вреда здоровью: автореф. дис. ... канд. юрид. наук. Саратов, 2008. - С. $18-19$.

${ }^{15}$ См.: Корчагин А.Г., Федотова Н.П. Уголовно-правовая политика борьбы с преступлениями умышленного причинения тяжкого вреда здоровью. - М.: Изд-во «Юрлитинформ», 2014. - С.57-58.

${ }^{16}$ См.: Шаматульский А. Неизгладимое обезображивание лица как признак тяжкого вреда здоровью // Актуальные проблемы российского права. 2014. № 8 (45). - С. 172.

${ }^{17}$ См.: Савельева О.Ю. Ответственность за причинение тяжкого вреда здоровью по российскому и зарубежному уголовному законодательству // Автореф. дис. канд. юрид. наук. - М., 2004. - С.8-9
} 
DOI: $10.7256 / 1811-9018.2015 .4 .13556$

При цитировании этой статьи сноска на doi обязательна

\section{Право и политика 4 (184) 2015}

уголовной ответственности ставят знак равенства между различными частями тела человека и его лицом.

Но лицо - это открытая часть тела, воспринимаемая окружающими и вызывающая у них отрицательную реакцию. Другие части тела скрыты одеждой, прической и не вызывают каких-либо отрицательных реакций у окружающих. Например, шрам, татуировки на шеи, скрытые прической, или с сексуальными сценами обезображивает тело, но их обладатель иного мнения, однако носит скрыто, исходя из общих понятий красоты и приличия.

Согласно п. 3 ч. 2 ст. 151 УПК РФ предварительное расследование по данной категории уголовных дел проводят следователи органов внутренних дел Российской Федерации. Следователь должен установить признаки тяжкого вреда здоровью, выразившегося в неизгладимом обезображивании лица. Так как он не обладает специальными познаниями, то назначает судебно-медицинскую экспертизу для установления признака неизгладимости. Что же касается признака обезображивания, то этот критерий следователь никак не обосновывает, так как его на протяжении большого периода времени устанавливает суд ${ }^{18}$. Например, после революции 1917 г. были введены временные «Правила для составления заключения о тяжести повреждений», утвержденные заместителем наркома здравоохранения 10 мая 1919 г., а с 16 ноября 1922 г. утвержденные Наркомздравом и Наркомюстом как постоянные, с 27 января 1928 г. они были уже введены в действие в новой редакции. В примечание 5 говорилось, что в какой мере повреждение обезображивает лицо у данного индивидуума, должно быть решено судьей, а не врачом ${ }^{19}$.

Обязанность установления наличия обезображивания лица предписывается суду подзаконным актом - Постановлением Правительства Российской Федерации № 522 от 17 августа 2007 г., а также изданным на основании указанного постановления Приказом Министерства здравоохранения и социального развития РФ от 24 апреля 2008 г. № $194 \mathrm{H}^{20}$. Обезображивание лица

\footnotetext{
${ }^{18}$ См.: «Правила определения степени тяжести вреда, причиненного здоровью человека», утвержденные постановлением Правительства РФ от 17.08.2007 № 522 // Собрание законодательства Российской Федерации от 27 августа 2007 г. № 35 ст. 4308; «Медицинские критерии определения степени тяжести вреда, причиненного здоровью человека», утвержденные приказом Минздравсоцразвития России от 24.04.2008 № 194н.// «Российская газета» от 5 сентября 2008 г. № 188 ,

${ }^{19}$ См.: Путинцев В.А., Абрамов С.С. Неизгладимое обезображивание лица // Судебно-медицинская экспертиза. №3. 2011. - С. 61.

${ }^{20}$ См.: «Правила определения степени тяжести вреда, причиненного здоровью человека», утвержденные постановлением Правительства РФ от 17.08.2007 № 522 // Собрание законо-
}

определяется судом по степени посттравматического искажения статических и динамических характеристик лица, которых в настоящее время не существует, поэтому судьи при решении данного вопроса исходят из своего внутреннего убеждения ${ }^{21}$.

Полномочия суда в уголовном судопроизводстве регламентированы в ст. 29 УПК РФ. Так, согласно п.3 ч. 2. суд может поместить, не находящихся под стражей подозреваемого, обвиняемого, в медицинский или психиатрический стационар для производства соответственно судебно-медицинской или психиатрической экспертизы. Среди полномочий не предусмотрено осуществление судом функции установления степени тяжести вреда, причиненного здоровью человека, выразившегося в неизгладимом обезображивании его лица, поэтому его установление является нарушением действующего уголовно-процессуального законодательства, так как деятельность суда в данном случае регламентируется подзаконными актами.

Если ранее при действии УПК РСФСР на суд согласно ст. 20 возлагалась обязанность полного и всестороннего исследования обстоятельств по делу, то данная деятельность была вполне допустимой. Однако с введением принципа состязательности сторон полномочия суда ограничены. Обратим внимание, что в настоящее время вновь ставится вопрос об установлении объективной истины по уголовным делам $^{22}$. Сложившаяся правоприменительная практика свидетельствует, что применительно к обезображиванию лица, в деле нет доказательств, представленных следователем. Этот квалифицирующий признак вреда будет установлен позже судом самостоятельно на основании эстетических критериев и своего субъективного восприятия внешнего вида потерпевшего в ходе судебного разбирательства. Следовательно, государственный обвинитель не имеет возможности представлять доказательства и участвовать в их исследо-

дательства Российской Федерации от 27 августа 2007 г. № 35 ст. 4308; «Медицинские критерии определения степени тяжести вреда, причиненного здоровью человека», утвержденные приказом Минздравсоцразвития России от 24.04.2008 № 194н.// «Российская газета» от 5 сентября 2008 г. № 188 ,

${ }^{21}$ См.: Клевно В.А., Богомолова И.Н., Заславский Г.И. и др. Судебно-медицинская экспертиза вреда здоровью. Руководство. М., 2009; Михайлов С.С. (ред.). Международная анатомическая номенклатура (с официальным списком русских эквивалентов). - М.: Медицина 1980.

22 Проект федерального закона «О внесении изменений в Уголовно-процессуальный кодекс Российской Федерации в связи с введением института установления объективной истины по уголовному делу» // http://www.sledcom.ru/discussions/?SID=3551. Дата обращения 25.10.2014. 
вании, а также высказать своё мнение о применении уголовного закона (ч. 5 ст. 246 УПК РФ),

Оценка суда выражает его мнение, которая может быть справедливой или несправедливой, исходя из его субъективных представлений о прекрасном и безобразном, уродливом и отталкивающем виде лица, и они не требует от него разъяснений и обоснований оценки. Здесь проявляется предельная субъективность, индивидуальность ценностных предпочтений, основанная как на стереотипных, так и на собственных вкусовых представлениях суда. Критерием такой справедливости является субъективность, но не познание в области эстетических оценок внешности человека. Даже общепринятые суждения о красивом имеют неоднозначную оценку, например, полные губы, толстые губы и др.

Исходя из изложенного, мы согласны с мнением, что наделение суда правом устанавливать обезображивание как признак вреда, причиненного здоровью человека, является ошибочным, так как возлагает на суд несвойственную ему функцию обвинения. Оставление функции установления факта обезображивания лица на судейское усмотрение свидетельствует о несовершенстве действующего законодательства, отрицательно сказывающимся на авторитете суда и уголовного закона ${ }^{23}$.

А.В. Гришин предложил следующий алгоритм действий участников процесса при установлении последствий совершенного преступления:

- обнаружив на лице потерпевшего рубец, образовавшийся на месте раны, и, установив его неизгладимость, судебно-медицинский эксперт, отвечая на вопрос следователя о степени вреда здоровью потерпевшего (ст.196 УПК РФ), установит наличие легкого вреда здоровью, по признаку кратковременного расстройства здоровья;

- следователь как субъект, не наделенный действующим законодательством функцией установления обезображивания лица, выполнит предварительную квалификацию преступления и подготовит для передачи в суд дело с обвинительным заключением с указанием на выявленные последствия, содержащие признаки преступления, предусмотренного ст. 115 УК РФ «Умышленное причинение легкого вреда здоровью»;

- судья, на этапе судебного разбирательства, установив своим усмотрением наличие «обезображивания лица», переквалифицирует преступление на преступление иной категории - более тяжкое, предусмотренное ст. 111 УК РФ «Умышленное причинение тяжкого вреда здоровью» 24.

\footnotetext{
${ }^{23}$ См.: Гришин А.В. О проблемах квалификации неизгладимого обезображивания лица. Дата обращения 20.10. 2014 г.

${ }^{24}$ См.: Там же.
}

Данный алгоритм действий, на наш взгляд, является спорным. Во-первых, ч.1 ст. 115 УК РФ это дело частного обвинения, которое согласно ч. 2 ст. 20 УПК РФ возбуждается не иначе как по заявлению потерпевшего и подлежит прекращению связи с примирением потерпевшего с обвиняемым. Потерпевший после мирового соглашения с обвиняемым может прийти к выводу, что шрам не так уж уродлив, да и вообще, шрамы украшают мужчину. Здесь проявляется конфликт эстетических оценок одного и того же повреждения с позиции разных субъектов. Безусловно, следователь и суд могут иметь по этому вопросу свое собственное суждение, но основополагающей является позиция потерпевшего, который считаем себя нормальным. Во-вторых, согласно ч. 3 ст. 150 УПК РФ предварительное расследование проводится в форме дознания и по окончанию составляется обвинительный акт (ст.225 УПК РФ). В-третьих, дела частного обвинения подсудны мировому судье, так как наказание не превышает 3 лет лишения свободы (ст.31 УПК РФ), в то время как по ст. 111 УК РФ наказание может быть до восьми лет лишения свободы. Если даже всё это оставить без внимания, то нельзя соблюсти требования ч. 2 ст. 252 УПК РФ: изменение обвинения в судебном разбирательстве допускается, если этим не ухудшается положение подсудимого и не нарушается его право на защиту.

Полагаем, спорным является и предложение о принятие Постановления Пленумом Верховного Суда Российской Федерации, в котором должно быть разъяснено, что вопрос о наличии обезображивания лица должен решаться судом с учетом характера, локализации, степени неизгладимости повреждений. Именно суд, исходя из объективных критериев, путем сопоставления внешности потерпевшего до причинения повреждения и после должен установить факт обезображивания. Следует отметить, что нередко показания потерпевших по таким делам страдают необъективностью. Суд в таких случаях должен руководствоваться объективными критериями, т.к. у потерпевшего может быть завышенное представление о своей внешности ${ }^{25}$.

Исходя из требований действующего уголовнопроцессуального закона, следователь должен установить наличие неизгладимости обезображивания лица путём привлечения специальных познаний экспертов.

\footnotetext{
${ }^{25}$ См.: Галюкова М.И. Неизгладимое обезображивание лица как признак тяжкого вреда здоровью. URL: http:// www.rusnauka.com/8. NPE2007/Pravo/18984.doc.htm).
} 


\section{Право и политика 4 (184) • 2015}

Применительно к неизгладимости лица, то этот вопрос решает судебно-медицинский эксперт ${ }^{26}$. А вот установление последствий преступного деяния в виде «неизгладимого обезображивания лица» судебно-медицинским экспертом ${ }^{27}$ вызвало возражение. Так, П.А. Дубовец, выступая против отнесения решения вопроса о степени обезображивания лица к судебно-медицинской экспертизе, отметил, что это компетенция судебных органов. Исключением могут быть случаи, когда суд придет к выводу об отсутствии обезображивания лица и предложит эксперту определить степень тяжести только самого повреждения ${ }^{28}$.

В настоящее время высказано предложение, что анатомические вопросы обезображивания лица будут решаться в рамках нового вида медико-криминалистической экспертизы, определяющей степень изменения внешнего вида лица методами, разработанными в судебно-портретной экспертизе ${ }^{29}$. Приведенное мнение заслуживает внимания, в той части, что вопрос обезображивания лица решается на стадии предварительного расследования экспертами, а не судом в судебном разбирательстве. Однако, названая экспертиза, не предназначена для определения эстетической оценки внешности человека.

Так, в соответствии с правилами производства в бюро СМЭ физико-технические (медико-криминалистические) экспертизы проводят эксперты-медики, прошедшие соответствующую специализацию. Объектами исследования являются труп неизвестного лица, скелетированный, иногда расчлененный труп, отдельные его части, костные останки, извлеченные из трупа раны и кости с повреждениями, а также травмировавшее орудие и одежда. Эксперты устанавливают характер и механизм образования повреждения; травмировавший предмет по повреждениям на теле и одежде; механизм образования следов крови на орудии, одежде, других объектах судебно-медицинской экспертизы; по костным останкам определяют их видовую, возрастную принадлежность, рост; производят идентификацию и определяют давность захоронения трупа или его останков.

\footnotetext{
${ }^{26}$ См.: Трынкина И.А. Неизгладимое обезображивание лица как признак тяжкого телесного повреждения // Вторая науч. конф. Киев. отд-я Украин. науч. об-ва судеб. медиков и криминалистов: Реф. докл. - Киев, 1956. - С.15.

27 См.: Гришин А.В. О проблемах квалификации неизгладимого обезображивания лица. Дата обращения 20.10. 2014 г.

${ }^{28}$ См.: Дубовеи П.А. Ответственность за телесные повреждения по советскому уголовному праву. - М.: Юрид. лит., 1964. - С. 75.

${ }^{29}$ См.: Путинцев В.А., Абрамов С.С. Неизгладимое обезображивание лица // Судебно-медицинская экспертиза. №3. 2011. - С. 60.
}

В соответствии с МВД РФ № 349 от 21 июля 1993 года «Об организации медико-криминалистического обеспечения установления личности неопознанных трупов» в экспертно-криминалистических подразделениях были созданы отделения (группы) специалистов по медико-криминалистическому обеспечению раскрытия и расследования тяжких преступлений против личности, установления личности неопознанных трупов. Специалисты производят исследования, связанные с вопросами идентификации личности, орудий совершения преступлений, определения причин и давности смерти, описания внешности и составления словесного портрета неопознанного трупа, выявление идентификационных признаков для установления личности погибшего $(\text { умершего })^{30}$.

Что же касается методов судебно-портретной экспертизы, то они применяются с целью идентификации лица или диагностики его отдельных характеристик (пол, возраст, расовая принадлежность и т.д.) по внешности, запечатленной на фотографии или на видеозаписи. Научными основами этой экспертизы являются не эстетические критерии и оценки, а данные антропологии, общей анатомии, топографической анатомии и разработанные на этой основе положения криминалистики о возможности отождествления человека по признакам внешности. В качестве объектов экспертизы выступают фотоснимки живых лиц и трупов, посмертные маски (слепки с лица трупа), череп трупа неизвестного лица, скульптурные и графические портреты, рисованные и композиционнорисованные портреты.

Следовательно, данные методы не пригодны для определения обезображивания лица: во-первых, объектом исследования является не лицо, а разноракурсные фотоснимки; фотопортреты лиц, сфотографированных со значительным разрывом во времени; ретушированные фотоснимки, фотоснимки, изготовленные с помощью так называемых цифровых фотоаппаратов с последующим воспроизведением электронного изображения. Во-вторых, данные методы направлены на определение идентификационной значимости признаков внешности ${ }^{31}$, а не их эстетическом восприятии и значении. Эксперт решает проблему возможного портретного сходства, при этом он подвержен субъективизму в оценке признаков

\footnotetext{
${ }^{30}$ См.: Акопов В.И. Медико-криминалистическая идентификация личности неопознанного трупа / bsm.tomsk.ru/Articles_1.htm. Дата обращения 20.10. 2014 г.

${ }^{31}$ См.: Приложение № 2 к Приказу МВД России от 29 июня 2005 года № 511; Зинин А.М. Судебно-портретная экспертиза (современное состояние и актуальные вопросы)// Электронный ресурс, 2008. Дата обращения 25.10. 2014 г.
} 
внешности. В случаях невозможности решить вопрос о тождестве изображенных лиц в связи с недостаточностью отобразившихся признаков эксперт делает вывод, что не представилось возможным установить тождество.

Полагаем, для правильной оценки обезображивания лица следователь может назначить проведение эстетической экспертизы, поручив её производство художникам-портретистам или специалистам в области изобразительного искусства, которые в заключении обоснуют объективные критерии наличие или отсутствие обезображивания лица, учитывая национальные анатомические особенности и представления о красоте и неповторимости. Данное заключение экспертов будет для следователя основанием предварительной квалификации причинения тяжкого вреда здоровью в виде обезображивания лица (ч. 1 ст. 111 УК РФ). Тем самым следователь не устраняется от вменения лицу факта обезображивания, а на суд в дальнейшем возлагается лишь функция оценки представленного заключения при обосновании своих выводов. По аналогии с установлением состояния аффекта, когда заключение судебно-психологической экспертизы о наличии аффекта, судом тщательно исследуется и делается выводу об отсутствии либо наличии состояния аффекта.

Для применения предлагаемого решения в судебно-следственной практике, необходимо внести изменения в Постановление Правительства Российской Федерации № 522 от 17 августа 2007 г., а также в Приказ Министерства здравоохранения и социального развития РФ от 24 апреля 2008 г. № 194н, что степень обезображивания лица определяется экспертом, обладающим специальными познания в области эстетической оценки внешнего облика человека.

\section{Библиография:}

1. Познышев С.В. Очерк основных начал науки уголовного права. Особенная часть. - М.,1923.

2. Капустин А.В. О некоторых вопросах судебно-медицинской экспертизы степени тяжести телесных повреждений // Суд. мед. эксперт.1991.№3.

3. Путинцев В.А., Абрамов С.С. Неизгладимое обезображивание лица // Судебно-медицинская экспертиза. №3. 2011.

4. Галюкова М.И. Неизгладимое обезображивание лица как признак тяжкого вреда здоровью. URL: http:// www.rusnauka. com/8.NPE2007/Pravo/18984.doc.htm).

5. Корчагин А.Г., Федотова Н.П. Уголовно-правовая политика борьбы с преступлениями умышленного причинения тяжкого вреда здоровью. - М.: Изд-во «Юрлитинформ», 2014.

6. Михайлов С.С. (ред.). Международная анатомическая номенклатура (с официальным списком русских эквивалентов). - М: Медицина 1980.

7. Дыскин Е.А., Исаков В.Д., Колкутин В.В., Путинцев В.А. Некоторые экспертные критерии неизгладимости при повреждениях лица // Актуальные вопросы теории и практики судебной медицины. Сборник трудов. - Санкт-Петербург. 1996.

8. Топографическая анатомия и оперативная хирургия: учебник / Каган И.И., Чемезов С.B. 2009. http://www.studmedlib.ru/ documents/ISBN9785970410578-A010.html. Дата обращения 20.10. 2014 г.

9. Пантелеев И.Ф. Идентификация человека по признакам внешности // Криминалистика: Учебник / Под ред. И.Ф. Пантелеева, Н.А. Селиванова. - М.: Юрид. лит., 1993.

10. Беляков А.А. Идентификация личности человека по признакам внешности // Криминалистика: учеб. Для вузов /И.Ф. Герасимов, Л.Я. Драпкин, И.П. Ищенко и др.; Под. ред. И.Ф. Герасимова, Л.Я. Драпкина. - М.: Высш. шк., 1994.

11. Эминов В.Е., Юрин Г.С. Использование при расследовании составных фотографических и рисованных портретов. - М.: ВИИПП, 1973.

12. Читлов Д.С. Охрана здоровья граждан от тяжких насильственных посягательств. - Саратов, 1974.

13. Поликарпова И.В. Уголовная ответственность за умышленное причинение тяжкого вреда здоровью. - М.: Изд-во «Юрлитинформ», 2009.

14. Поликарпова И.В. Уголовная политика России в отношении посягательств на здоровье и ее влияние на квалификацию преступлений: на примере ответственно ᄀсти за умышленное причинение тяжкого вреда здоровью: автореф. дис. ... канд. юрид. наук. - Саратов, 2008.

15. Шаматульский А. Неизгладимое обезображивание лица как признак тяжкого вреда здоровью // Актуальные проблемы российского права. 2014. № 8 (45).

16. Савельева О.Ю. Ответственность за причинение тяжкого вреда здоровью по российскому и зарубежному уголовному законодательству.// Автореф. дис. канд. юрид. наук. - М., 2004.

17. Клевно В.А., Богомолова И.Н., Заславский Г.И. и др. Судебно-медицинская экспертиза вреда здоровью. Руководство. - М., 2009.

18. Михайлов С.С. (ред.). Международная анатомическая номенклатура (с официальным списком русских эквивалентов). М.: Медицина 1980.

19. Гришин А.В. О проблемах квалификации неизгладимого обезображивания лица. Дата обращения 20.10. 2014.

20. Трынкина И.А. Неизгладимое обезображивание лица как признак тяжкого телесного повреждения // Вторая науч. конф. Киев. отд-я Украин. науч. об-ва судеб. медиков и криминалистов: Реф. докл. - Киев, 1956. 
DOI: $10.7256 / 1811-9018.2015 .4 .13556$

При цитировании этой статьи сноска на dоі обязательна

\section{Право и политика 4 (184) $\bullet 2015$}

21. Дубовец П.А. Ответственность за телесные повреждения по советскому уголовному праву. - М.: Юрид. лит., 1964.

22. Акопов В.И. Медико-криминалистическая идентификация личности неопознанного трупа / bsm.tomsk.ru/Articles_1.htm. Дата обращения 20.10. 2014 г.

\section{References (transliterated):}

1. Poznyshev S.V. Ocherk osnovnykh nachal nauki ugolovnogo prava. Osobennaya chast'. - M.,1923.

2. Kapustin A.V. O nekotorykh voprosakh sudebno-meditsinskoi ekspertizy stepeni tyazhesti telesnykh povrezhdenii // Sud. - med. ekspert.1991.№3.

3. Putintsev V.A., Abramov S.S. Neizgladimoe obezobrazhivanie litsa // Sudebno-meditsinskaya ekspertiza. №3. 2011.

4. Galyukova M.I. Neizgladimoe obezobrazhivanie litsa kak priznak tyazhkogo vreda zdorov’yu. URL: http:// www.rusnauka.com/8. NPE2007/Pravo/18984.doc.htm).

5. Korchagin A.G., Fedotova N.P. Ugolovno-pravovaya politika bor'by s prestupleniyami umyshlennogo prichineniya tyazhkogo vreda zdorov'yu. - M.: Izd-vo «Yurlitinform», 2014.

6. Mikhailov S.S. (red.). Mezhdunarodnaya anatomicheskaya nomenklatura (s ofitsial'nym spiskom russkikh ekvivalentov). - M: Meditsina 1980.

7. Dyskin E.A., Isakov V.D., Kolkutin V.V., Putintsev V.A. Nekotorye ekspertnye kriterii neizgladimosti pri povrezhdeniyakh litsa // Aktual'nye voprosy teorii i praktiki sudebnoi meditsiny. Sbornik trudov. - Sankt-Peterburg. 1996.

8. Topograficheskaya anatomiya i operativnaya khirurgiya: uchebnik / Kagan I.I., Chemezov S.V. 2009. http://www.studmedlib.ru/ documents/ISBN9785970410578-A010.html. Data obrashcheniya 20.10. 2014 g.

9. Panteleev I.F. Identifikatsiya cheloveka po priznakam vneshnosti // Kriminalistika: Uchebnik / Pod red. I.F. Panteleeva, N.A. Selivanova. - M.: Yurid. lit., 1993.

10. Belyakov A.A. Identifikatsiya lichnosti cheloveka po priznakam vneshnosti // Kriminalistika: ucheb. Dlya vuzov /I.F. Gerasimov, L.Ya. Drapkin, I.P. Ishchenko i dr.; Pod. red. I.F. Gerasimova, L.Ya. Drapkina. - M.: Vyssh. shk., 1994.

11. Eminov V.E., Yurin G.S. Ispol'zovanie pri rassledovanii sostavnykh fotograficheskikh i risovannykh portretov. - M.: VIIPP, 1973.

12. Chitlov D.S. Okhrana zdorov'ya grazhdan ot tyazhkikh nasil'stvennykh posyagatel'stv. - Saratov, 1974.

13. Polikarpova I.V. Ugolovnaya otvetstvennost' za umyshlennoe prichinenie tyazhkogo vreda zdorov’yu. - M.: Izd-vo «Yurlitinform», 2009.

14. Polikarpova I.V. Ugolovnaya politika Rossii v otnoshenii posyagatel'stv na zdorov'e i ee vliyanie na kvalifikatsiyu prestuplenii: na primere otvetstvenno $\neg$ sti za umyshlennoe prichinenie tyazhkogo vreda zdorov’yu: avtoref. dis. ... kand. yurid. nauk. - Saratov, 2008.

15. Shamatul'skii A. Neizgladimoe obezobrazhivanie litsa kak priznak tyazhkogo vreda zdorov'yu // Aktual'nye problemy rossiiskogo prava. 2014. № 8 (45).

16. Savel'eva O.Yu. Otvetstvennost' za prichinenie tyazhkogo vreda zdorov'yu po rossiiskomu i zarubezhnomu ugolovnomu zakonodatel'stvu.// Avtoref. dis. kand. yurid. nauk. - M., 2004.

17. Klevno V.A., Bogomolova I.N., Zaslavskii G.I. i dr. Sudebno-meditsinskaya ekspertiza vreda zdorov'yu. Rukovodstvo. - M., 2009.

18. Mikhailov S.S. (red.). Mezhdunarodnaya anatomicheskaya nomenklatura (s ofitsial'nym spiskom russkikh ekvivalentov). - M.: Meditsina 1980.

19. Grishin A.V. O problemakh kvalifikatsii neizgladimogo obezobrazhivaniya litsa. Data obrashcheniya 20.10. 2014.

20. Trynkina I.A. Neizgladimoe obezobrazhivanie litsa kak priznak tyazhkogo telesnogo povrezhdeniya // Vtoraya nauch. konf. Kiev. otd-ya Ukrain. nauch. ob-va sudeb. medikov i kriminalistov: Ref. dokl. - Kiev, 1956.

21. Dubovets P.A. Otvetstvennost' za telesnye povrezhdeniya po sovetskomu ugolovnomu pravu. - M.: Yurid. lit., 1964.

22. Akopov V.I. Mediko-kriminalisticheskaya identifikatsiya lichnosti neopoznannogo trupa / bsm.tomsk.ru/Articles_1.htm. Data obrashcheniya 20.10. $2014 \mathrm{~g}$. 